\title{
Nifedipine-Induced gingival overgrowth
}

\section{Aumento gengival induzido por nifedipina}

Ornella FLORIO

Maysa TFOUNI

DDS - Postgraduate student - Department of Biosciences and Oral Diagnosis - School of Dentistry of São José dos Campos - UNESP Univ Estadual Paulista - Brasil.

Ivan BALDUCCI

MS - Assistent Professor - Department of Social Science and Pediatric Dentistry - School of Dentistry of São José dos Campos UNESP - Univ Estadual Paulista - Brasil.

Andrea Carvalho DE MARCO $\mathrm{PhD}$ - Assistent Professor - Department of Diagnosis and Surgery - School of Dentistry of São José dos Campos - UNESP - Univ Estadual Paulista - Brasil.

Maria Aparecida Neves JARDINI $\mathrm{PhD}$ - Associate Professor - Department of Diagnosis and Surgery - School of Dentistry of São José dos Campos - UNESP - Univ Estadual Paulista - Brasil.

Janete Dias ALMEIDA

$\mathrm{PhD}$ - Associate Professor - Department of Biosciences and Oral Diagnosis - School of Dentistry of São José dos Campos - UNESP Univ Estadual Paulista - Brasil.

\section{AbstRact}

Objective: The objective of the present study was to evaluate gingival overgrowth induced by nifedipine and to correlate it with plaque accumulation. Material and Methods: Sixty patients were divided into a treated group $(\mathrm{n}=30)$ consisting of hypertensive patients long-term treated with nifedipine and a control group $(n=30)$ consisting of patients without arterial hypertension. The following exams were performed on the first visit: anamnesis, measurement of blood pressure, weight and height, extra- and intraoral examination, and determination of the vertical and horizontal gingival overgrowth indices, plaque index, and bleeding index. The measurements were repeated after 30 days. Results: Most patients using nifedipine (60.7\%) presented grade I horizontal gingival overgrowth (1 to $2 \mathrm{~mm}$ ), with $3.6 \%$ showing minimum vertical gingival overgrowth. On the return visit, the plaque index was reduced by $8.3 \%$ and bleeding on probing was reduced by $1.5 \%$. The individuals of control group, presented neither vertical gingival overgrowth nor horizontal, the plaque index was reduced by $7.2 \%$ and bleeding on probing was reduced by $5.3 \%$. A significant difference in the horizontal gingival overgrowth index was observed between the treated and control groups (chi-square test, $\mathrm{p}=0.015, \mathrm{p}<$ 0.05 ). Conclusions: In the present study, authors conclude that the presence of dental biofilm and inflammation influences the degree of gingival overgrowth in patients using nifedipine.

\section{KEYWORDS}

Gingival overgrowth; Nifedipine; Periodontal diseases.

\section{Resumo}

Objetivo: O objetivo deste estudo foi avaliar o aumento gengival induzido por nifedipina e correlacioná-lo com o acúmulo de placa. Material e Métodos: Sessenta pacientes foram divididos em um grupo de hipertensos crônicos, sob tratamento contínuo com nifedipina, $(\mathrm{n}=30)$ e um grupo controle, pacientes saudáveis, sem hipertensão $(n=30)$. Os seguintes exames foram realizados na primeira consulta: anamnese, aferição da pressão arterial, peso, altura, exame intra e extra-bucal, índices de aumento gengival vertical e horizontal, índice de placa e índice de sangramento. Os exames foram realizados novamente após 30 dias. Resultados: A maioria dos pacientes sob uso de nifedipina $(60,7 \%)$ apresentou aumento gengival horizontal grau I (1 a $2 \mathrm{~mm})$, e 3,6\% demonstraram mínimo aumento gengival vertical. $\mathrm{Na}$ visita de retorno, o índice de placa foi reduzido em 8,3\% e sangramento à sondagem em $1,5 \%$. Os indivíduos do grupo controle não apresentaram aumento gengival vertical e nem horizontal, o índice de placa foi reduzido em 7,2\% e sangramento à sondagem em 5,3\%. Diferença significativa no índice de aumento gengival horizontal foi observada entre os grupos teste e controle $(p=0,015, p<0,05)$. Conclusão: Neste estudo os autores concluíram que a presença do biofilme dental e a inflamação influenciam no grau de aumento gengival em pacientes sob tratamento com nifedipina.

\section{UNITERMOS}

Aumento gengival; Nifedipina; Doença periodontal. 


\section{BACKGROUND}

Drug-induced gingival overgrowth is characterized by fibrous and excessive growth of gingival tissues $[1,2]$. Calcium channel blockers such as nifedipine used for the treatment and/or maintenance of blood pressure are known to induce gingival hyperplasia. The exact mechanism of induction is unclear, although several studies suggest that resident fibroblasts produce more collagen and other extracellular matrix molecules than normal [2]. More recently, studies have shown that the epithelial thickness encountered in gingival overgrowth could be associated with an increase in the mitotic activity of the epithelium, as measured by the expression of proliferation markers [3]; in rats, nifedipine itself did not lead to gingival enlargement, but in the presence of biofilm accumulation, nifedipine yielded greater gingival enlargement and periodontal inflammation, however there was no increase in periodontal destruction [4].

Gingival hyperplasia resulting from the use of calcium channel blockers has been reported both in medical and dental literature. However, the prevalence of this growth and its relationship with age, dosage, duration of intake, and oral hygiene has not been adequately addressed [5].

The pathogenesis of nifedipine-induced gingival overgrowth condition remains unclear; it is thought to be multifactorial. Various risk factors including drug variables, concomitant medication, periodontal variables and genetic factors have been associated with this unpleasant clinical condition [6,7]. Moreover, age and gender have also been considered as important risk factors for drug-induced gingival overgrowth [6].

Gingival hyperplasia can cause changes in tooth eruption,xerostomiaandpaininthetemporomandibular joint and increase the predisposition to caries. The diagnosis of gingival overgrowth is made based on clinical examination and a history of the use of predisposing drugs. However, histopathological analysis should not be underestimated $[8,9]$. Gingival enlargement is usually noted within one to two months after the initiation of nifedipine therapy and appears to primarily affect interdental papilla and labial gingiva $[6,10]$, considering that the approved usages for nifedipine are the long-term treatment of hypertension (high blood pressure) and angina pectoris [11].

The clinical management of the gingival overgrowth presents a continuous challenge. Treatment consists of periodic prophylaxis, scaling and, in more critical stages, periodontal surgery [12].
The influence of plaque on the induction of gingival overgrowth by calcium channel blockers in humans is not very clear. However, oral hygiene seems to affect the severity of this condition [13]. Güncü et al. [14], showed that neither gingival crevice fluid nor plasma nifedipine levels appeared to be a risk factor for nifedipine-induced gingival overgrowth.

It has been shown that nifedipine-induced gingival enlargement may be reduced or prevented by good plaque control, aimed at reducing gingival inflammation [15,16]. Ellis et al. [17], assessed plaque index and concluded that plaque-induced gingival inflammation may simply exacerbate the effect by enhancing the gingival changes, but the presence of gingival inflammation is an important cofactor in the expression of gingival overgrowth. Recently, Sousa et al. [18], established that there was an association between gingival overgrowth and periodontal variables, except for plaque index and that the presence of gingival inflammation was the main risk fator for the occurence of nifedipine-induced gingival overgrowth.

The objective of the present study was to evaluate gingival overgrowth induced by nifedipine and to correlate it with plaque accumulation.

\section{Material and Methods}

For this study, 60 patients were examined and divided into two groups. The nifedipine group consisted of 30 hypertensive patients taking nifedipine, and the control group consisted of 30 patients without arterial hypertension who did not use any drug of this nature. The patients received detailed information about the objectives of the study and signed a free informed consent form. The study was approved by the Research Ethics Committee of the São José dos Campos Dental School, São Paulo State University (UNESP) (protocol 050/2003-PH/ CEP).

Inclusion criteria were dentate or partially dentate patients with at least four anterior lower teeth and under treatment with nifedipine for at least 6 months. Excluded criteria were patients using anticonvulsant drugs, cyclosporine and calcium channel blockers other than nifedipine, and patients with systemic disorders affecting gingival tissues.

During the first visit, the patients were submitted to anamnesis, measurement of blood pressure, weight and height, and extra- and intraoral examination. The measurements were repeated on a second visit after 30 days. 


\section{Periodontal Examination}

Probing pocket depth (PPD) and the bleeding index were measured at 6 sites around each tooth [19]. The vertical gingival overgrowth index (GOI) was determined according to Miller and Damm [20] as shown in Table 1 .

\section{Table 1 - Vertical gingival oVergrowth indeX} according to Miller and Damm.

\begin{tabular}{l|c|c}
\hline Grade & Clinical aspect & Criterion \\
\hline 0 & Normal gingiva & No alteration \\
\hline 1 & $\begin{array}{c}\text { Minimal } \\
\text { overgrowth }\end{array}$ & $\begin{array}{c}£ 2 \mathrm{~mm} \text {, with the gingiva covering the } \\
\text { cervical third or less of the anatomic } \\
\text { crown }\end{array}$ \\
\hline 3 & $\begin{array}{c}\text { Moderate } \\
\text { overgrowth }\end{array}$ & $\begin{array}{c}2 \text { to } 4 \mathrm{~mm} \text { and/or gingiva covering the } \\
\text { middle third of the anatomic crown }\end{array}$ \\
\hline
\end{tabular}

For calculation of the horizontal GOI [21], the periodontal probe was positioned perpendicularly to the interdental papilla and the distance from the enamel surface at the point of contact to the external surface of the papilla was measured (Table 2).

TABLE 2 - HoRizontal gingival OVERgRowth INDEX.

\begin{tabular}{c|c}
\hline Grade & Criterion \\
\hline 0 & $<1 \mathrm{~mm}$ \\
\hline 1 & 1 to $2 \mathrm{~mm}$ \\
\hline 2 & $>2 \mathrm{~mm}$ \\
\hline
\end{tabular}

For calculation of the vertical and horizontal indices, the anterior lower teeth were examined and the higher grade was considered when more than one pattern was observed in this group of teeth. Finally, the plaque index was determined [22]. The patients were then instructed regarding oral hygiene and submitted to professional plaque control.

To ensure the uniformity of the measurements and to reduce intraobserver variation, calibration was performed by probing 10 patients, with the measurements being repeated after 7 days under the same conditions [23]. The values obtained were subjected to the Test $t$ (Student) paired samples, which indicates that the average values did not differ $(\mathrm{t}=1.06 ; \mathrm{gl}=89 ; \mathrm{p}=0.291>0.05)$.

\section{Statistical Analysis}

Mean values were compared between observers by the Student t-test for paired samples. Horizontal gingival overgrowth $(\mathrm{mm})$ as a function of the other variables studied was evaluated using multiple regression analysis. The chi-square test and Fisher's exact test were used to compare proportions between the control and nifedipine group according to the period of assessment and the clinical variables studied. A level of significance of 5\% was adopted.

\section{RESULTS}

Sixty patients participated in the initial exam and their demographic characteristics are shown in Table 3.

Table 3 - Demographic characteristics and MEDICATION OF THE 60 PATIENTS WHO PARTICIPATED IN THE STUDY.

\begin{tabular}{c|c|c}
\hline Characteristics & Nifedipine group (\%) & Control group (\%) \\
\hline Gender & & \\
\hline Male & 39.3 & 25 \\
\hline Female & 60.7 & 75 \\
\hline Mean age (years) & & 42.4 \\
\hline Men & 60.8 & 44.6 \\
\hline Women & 56.8 & 44.1 \\
\hline General & 58.4 & 21.4 \\
\hline Smokers & 10.7 & 10.7 \\
\hline Bruxism & 10.7 & \\
\hline $\begin{array}{l}\text { Ingested drug dose } \\
\text { (mg)* }\end{array}$ & & - \\
\hline 10 & 28 & - \\
\hline 20 & 64 & - \\
\hline 25 & 8 & \\
\hline
\end{tabular}

*The mean duration of drug intake was 3 years and 7 months.

The mean age was 58 years in the nifedipine group and 44 years in the control group. Women predominated in both groups.

No lesions requiring the collection of material for histopathological and/or cytological analysis were observed in either group. 
The patients reported that they saw their physicians every 3 months, whereas they only saw their dentists in the case of some sign or symptom, especially pain.

The mean body mass index of patients using nifedipine was $30.12 \mathrm{~kg} / \mathrm{m} 2$, with these patients being classified as class II (moderate risk of obesity). Blood pressure was higher than $140 \times 90 \mathrm{mmHg}$ in $42.8 \%$ of nifedipine-treated patients at the time of assessment. Among control group patients, $84 \%$ had body mass index above $25 \mathrm{~kg} / \mathrm{m} 2$ and were advised to seek a physician.

Periodontal analysis revealed a reduction in the plaque index of $8.3 \%$ in the nifedipine group and of $7.2 \%$ in the control group. Bleeding on probing decreased by $1.5 \%$ in the treated group and by $5.3 \%$ in the control group (Table 4).

Table 4 - Distribution (absolute and relative (\%) FREQUENCY) OF CONTROL AND TAKING NIFEDIPINE PATIENTS AFTER PERIODONTAL ASSESSMENT

\begin{tabular}{|c|c|c|c|c|c|}
\hline \multirow{2}{*}{ Variable } & \multirow{2}{*}{ Criterion } & \multicolumn{2}{|c|}{ Nifedipine group } & \multicolumn{2}{|c|}{ Control group } \\
\hline & & First visit & Return & First visit & Return \\
\hline \multirow{2}{*}{$\begin{array}{l}\text { Vertical } \\
\text { gingival } \\
\text { overgrowth } \\
\text { index }\end{array}$} & $=0$ & $\begin{array}{c}29 \\
(96.7)\end{array}$ & $27(90)$ & $27(90)$ & $27(90)$ \\
\hline & ${ }^{1} 0$ & $1(3.3)$ & $3(10)$ & $3(10)$ & $3(10)$ \\
\hline \multirow{2}{*}{$\begin{array}{l}\text { Horizontal } \\
\text { gingival } \\
\text { overgrowth } \\
\text { index }\end{array}$} & $=0$ & $\begin{array}{c}11 \\
(36.7)\end{array}$ & & $\begin{array}{c}17 \\
(56.7)\end{array}$ & \\
\hline & ${ }^{1} 0$ & $\begin{array}{c}19 \\
(63.3)\end{array}$ & $24(80)$ & $13(43.3)$ & $15(50)$ \\
\hline \multirow{2}{*}{$\begin{array}{l}\text { Bleeding } \\
\text { on probing } \\
\text { index }\end{array}$} & Yes & $6(20)$ & $5(16.7)$ & $4(13.3)$ & $3(10)$ \\
\hline & No & $24(80)$ & $\begin{array}{c}25 \\
(83.3)\end{array}$ & $\begin{array}{c}26 \\
(86.7)\end{array}$ & $27(90)$ \\
\hline \multirow{2}{*}{$\begin{array}{l}\text { Plaque } \\
\text { índex }\end{array}$} & Yes & $8(26.7)$ & $6(20)$ & $5(16.7)$ & $2(6.7)$ \\
\hline & No & $\begin{array}{c}22 \\
(73.3)\end{array}$ & $24(80)$ & $\begin{array}{c}25 \\
(83.3)\end{array}$ & $\begin{array}{c}28 \\
(93.3)\end{array}$ \\
\hline \multirow{2}{*}{$\begin{array}{l}\text { Probing } \\
\text { pocket } \\
\text { depth }\end{array}$} & $£ 3$ & $8(26.7)$ & $5(16.7)$ & $\begin{array}{c}17 \\
(56.7)\end{array}$ & $\begin{array}{c}22 \\
(73.3)\end{array}$ \\
\hline & $>3$ & $\begin{array}{c}22 \\
(73.3)\end{array}$ & $\begin{array}{c}25 \\
(83.3)\end{array}$ & $13(43.3)$ & $8(26.7)$ \\
\hline
\end{tabular}

With all variables included in the model, the $\mathrm{F}$ test (ANOVA) indicated $p=0.066$. In this complete model, gender, bleeding index and age were identified as statistically significant variables. The model that best fitted the data, with an explanatory power of $40.4 \%$, included the variables gender, bleeding index, duration of drug intake, and age. When excluding duration of drug use, the model showed an explanatory power of $38.2 \%$ and all variables present in the model (gender, bleeding index and age) were statistically significant.

Comparison of the variables vertical and horizontal GOI, plaque index and PPD between the nifedipine and control groups, considering the first and return visit, was significant for the horizontal GOI and PPD (Table 5).

Table 5 - Comparison between the nifedipine AND CONTROL GROUPS ACCORDING TO THE PERIOD OF ASSESSMENT AND CLINICAL VARIABLES.

\begin{tabular}{|c|c|c|c|c|}
\hline \multirow{2}{*}{$\begin{array}{l}\text { Variable } \\
\text { Vertical gingival } \\
\text { overgrowth } \\
\text { index (grade } 0 \text { ) }\end{array}$} & \multicolumn{2}{|c|}{ First visit } & \multicolumn{2}{|c|}{ Return } \\
\hline & $\begin{array}{c}96.7 \text { vs } \\
90.0 \%\end{array}$ & $\mathrm{p}=0.612 \rrbracket$ & 90 vs $90 \%$ & $\mathrm{p}=1.00$ \\
\hline $\begin{array}{l}\text { Horizontal } \\
\text { gingival } \\
\text { overgrowth } \\
\text { index (grade 0) }\end{array}$ & $\begin{array}{c}36.7 \text { vs } \\
56.7 \%\end{array}$ & $\mathrm{p}=0.121$ & 20 vs $50 \%$ & $\mathrm{p}=0.015^{\star}$ \\
\hline $\begin{array}{l}\text { Bleeding on } \\
\text { probing index } \\
\text { (positive } \\
\text { diagnosis) }\end{array}$ & $\begin{array}{c}20 \text { vs } \\
13.3 \%\end{array}$ & $\mathrm{p}=0.488$ & $\begin{array}{c}16.7 \text { vs } \\
10 \%\end{array}$ & $\mathrm{p}=0.706 \rrbracket$ \\
\hline $\begin{array}{l}\text { Plaque índex } \\
\text { (positive } \\
\text { diagnosis) }\end{array}$ & $\begin{array}{c}26.7 \text { vs } \\
16.7 \%\end{array}$ & $\mathrm{p}=0.347$ & $\begin{array}{l}20 \mathrm{vs} \\
6.7 \%\end{array}$ & $\mathrm{p}=0.254 \rrbracket$ \\
\hline $\begin{array}{l}\text { Probing pocket } \\
\text { depth } \\
(>3 \mathrm{~mm})\end{array}$ & $\begin{array}{c}73.3 \text { vs } \\
43.3 \%\end{array}$ & $\mathrm{p}=0.018^{*}$ & $\begin{array}{c}83.3 \text { vs } \\
26.7 \%\end{array}$ & $\mathrm{p}=0.001^{\star}$ \\
\hline
\end{tabular}

$\otimes$ Fisher's exact test.
${ }^{*} \mathrm{p}<0.05$

\section{Discussion}

The present results permit the correlation of nifedipine-induced gingival overgrowth and oral hygiene since the association between the horizontal GOI and bleeding index was significant, and a decrease in the plaque and bleeding indices was observed in both the nifedipine and control groups after instruction about oral hygiene. A relationship has been reported between the severity of gingival overgrowth and periodontal conditions such as the presence of dental biofilm and bleeding on probing, i.e., the medication is a modifying factor in the presence of inflammation [24,25], although Güncü et al. [14] have showed that neither gingival crevice fluid nor plasma nifedipine levels appeared to be a risk factor for nifedipineinduced gingival overgrowth. Güncü et al. [14], also commented that improving the oral hygiene in patients using nifedipine may help control the degree of drug-induced gingival enlargement.

Huang et al. [25] have shown that inflammation is 
not the main factor in the pathogenesis of nifedipineinduced gingival overgrowth. The group with nifedipine-induced gingival overgrowth and the group with moderate periodontitis received periodontal treatment (scaling and root planing), in addition to oral hygiene instructions. The authors concluded that, once the inflammation factor is eliminated, gingival overgrowth is influenced by androgen metabolism as demonstrated by the significant number of androgen receptor-presenting cells in gingival tissue of susceptible patients of the nifedipine group.

Tavassoli et al. [24], observed that individuals using nifedipine with a mean age of 45 years presented a slight tendency toward gingival overgrowth compared to subjects with a mean age of 55 years. In the present study, statistical analysis showed a significant association between gingival overgrowth and age, with the mean age being 58 years in the nifedipine group and 44 years in the control group. Miranda et al. [26] found a significant difference in relation to age, and Thomason et al. [27] related a higher prevalence of gingival overgrowth in younger patients when a treatment association of nifedipine and cyclosporine was identified. In an experimental study in rats treated with cyclosporin A and nifedipine, Spolidorio et al. [28], found evident gingival overgrowth caused by nifedipine in young animals (15 and 30 days), whereas no significant growth was observed in adult rats (60 and 90 days), concluding that gingival overgrowth might be age dependent.

In the present study, the frequency of smokers was higher in the control group (21.4\%) than in the treated group $(10.7 \%)$. The prevalence of bruxism was the same in the two groups $(10.7 \%)$. In a similar study conducted by Miranda et al. [26], smoking was less prevalent and bruxism was slightly more frequent in the group treated with nifedipine compared to the control group.

The present study showed a mean duration of drug intake of 3 years and 7 months. Although Tavassoli et al. [24], reported a higher incidence of gingival overgrowth in patients using nifedipine for more than 4 years, some authors reported that gingival enlargement is usually noted within one to two months after the initiation of nifedipine therapy and appears to primarily affect interdental papilla and labial gingiva [2,10]. Miranda et al. [26], found no significant association between the degree of gingival overgrowth and nifedipine dose, although increased overgrowth is observed when patients are exposed to high doses of the drug. In the present study, the daily ingested drug dose was $10 \mathrm{mg}$ in $28 \%$ of the patients,
$20 \mathrm{mg}$ in $64 \%$ and $25 \mathrm{mg}$ in $8 \%$, with no significant difference.

Comparison of the presence of dental biofilm and bleeding on probing between the initial and final assessment at an interval of one month showed significant results in both groups. Bleeding on probing decreased by $5.3 \%$ in the control group and by $1.5 \%$ in the nifedipine group. Ellis et al. [17] showed that plaque index and bleeding index on probing were strongly correlated with the severity of gingival overgrowth in patients using nifedipine. Furthermore, analysis of the ultrastructure of the gingiva in cardiac patients showed increased deposition of wellorganized collagen fibers in gingival connective tissue of patients treated with nifedipine, especially in the transition zones between inflamed and healthy tissue [29].

Nifedipine may exert a synergistic and dosedependent effect with tumor necrosis factor alpha, a proinflammatory cytokine [30]. Thus, the degree of gingival inflammation (for example, resulting from precarious oral hygiene) may increase the sensitivity of tissue to the effects of nifedipine. The mechanism whereby nifedipine induces a connective tissue response has been investigated in rats [31]. The authors noted a reduction in collagen fiber phagocytosis by fibroblasts after 30 days of drug use before the macroscopic detection of gingival overgrowth. In contrast, Shimizu et al. [32], suggested that nifedipine induces epithelial hyperplasia not by an increase in keratinocyte proliferation but by prolongation of cell life through a reduction of apoptosis before epithelial hyperplasia is diagnosed. In the present study, no histopathological analysis was performed in either group since plaque control was efficient in the patients examined and no surgery was necessary.

With respect to the comparison of proportions between the treated and control groups according to period of assessment (initial and final), the clinical variables horizontal GOI and PPD were statistically significant. In the study of Sousa et al. [18], the probing depth (PD) did not differ significantly between the test and control groups, but in the studies of Barclay et al. [13]; Thomason et al. [27], the gingival overgrowth was associated with an increase in PD in both groups.

Many cardiologists no longer prescribe nifedipine. Yet many physicians and/or cardiologists are unaware of the relationship between nifedipine and gingival overgrowth as a side effect, indicating the importance of interaction between healthcare professionals. 


\section{Conclusions}

In this study, authors conclude that the presence of dental biofilm and inflammation influences the degree of gingival overgrowth in patients using nifedipine. The importance of patient guidance on the part of dentists in order to improve the quality of oral and general health has to be emphasized. To provide competent care to patients with hypertension, clinicians must understand the disease, its treatment, and impact on the patient's ability to undergo and respond to dental care.

\section{References}

1. Hassell TM, Hefti AF. Drug-induced gingival overgrowth: old problem, new problem. Crit Rev Oral Biol Med. 1991;2(1):103-37.

2. Seymour RA, Thomason JM, Ellis JS. The pathogenesis of drug-induced gingival overgrowth. J Clin Periodontol. 1996 Mar;23(3Pt1):165-75.

3. Castro LA, Elias LS, Oton-Leite AF, de Spíndula-Filho JV, Leles CR, Batista AC, et al. Long-term effects of nifedipine on human gingival epithelium: a histopathological and immunohistochemical study. J Oral Sci. 2010 Mar;52(1):5562.

4. Fernandes MI, Gaio EJ, Susin C, Rösing CK, Oppermann $\mathrm{RV}$, Rados PV. Effect of nifedipine on gingival enlargement and periodontal breakdown in ligature-induced periodontitis in rats. Arch Oral Biol. 2010 Jul;55(7):523-9.

5. Pedaballi P, Sundaram R, Ramachandran M. Prevalence of gingival enlargement secondary to calcium channel blockers in patients with cardiovascular diseases. J Indian Soc Periodontol. 2012 Jul;16(3):430-5.

6. Seymour RA, Ellis JS, Thomason JM. Risk factors for drug-induced gingival overgrowth. J Clin Periodontol. 2000 Apr;27(4):217-23.

7. Flynn JC, Henderson JS, Johnson RB. Synergism between nifedipine and cyclosporine $\mathrm{A}$ on the incorporation of [35S] sulfate into human gingival fibroblast cultures in vitro. J Clin Periodontol. 2006 Aug;41(4):316-21.

8. Bullon P, Gallardo I, Goteri G, Rubini C, Battino M, Ribas $\mathrm{J}$, et al. Nifedipine and cyclosporin affect fibroblast calcium and gingiva. J Dent Res. 2007 Apr;86(4):357-62.

9. Kanno CM, Oliveira JA, Garcia JF, Castro AL, Crivelini MM. Effects of cyclosporin, phenytoin, and nifedipine on the synthesis and degradation of gingival collagen in tufted capuchin monkeys (Cebus apella): histochemical and MMP-1 and -2 and collagen I gene expression analyses. J Periodontol. 2008 Jan;79(1):114-22.

10. Seymour RA, Heasman PA. Drugs and the periodontium. J Clin Periodontol. 1988 Jan;15(1):1-16.

11. Hypertension: The Clinical Management of Primary Hypertension in Adults: Update of Clinical Guidelines 18 and 34 [Internet]. Editors. National Clinical Guideline Centre (UK). Source London: Royal College of Physicians (UK); 2011 Aug.

12. Trackman PC, Kantarci A. Connective tissue metabolism and gingival overgrowth. Crit Rev Oral Biol Med. 2004 Jun;15(3):165-75.

13. Barclay S, Thomason JM, Idle JR, Seymour RA. The incidence and severity of nifedipine-induced gingival overgrowth. J Clin Periodontol. 1992 May;19(5):311-4.

14. Güncü GN, Cağlayan F, Dinçel A, Bozkurt A, Ozmen S, Karabulut E. Clinical and pharmacological variables as a risk factor for nifedipine-induced gingival overgrowth. Aust Dent J. 2007 Dec;52(4):295-9.

15. Seymour RA, Smith DG. The effect of a plaque control programme on the incidence and severity of cyclosporininduced gingival changes. J Clin Periodontol. 1991 Feb;18(2):107-10.

16. Pilloni A, Camargo PM, Carere M, Carranza FA Jr. Surgical treatment of cyclosporine A- and nifedipine-induced gingival enlargement: gingivectomy versus periodontal flap. J Periodontol. 1998 Jul;69(7):791-7.

17. Ellis JS, Seymour RA, Steele JG, Robertson P, Butler TJ, Thomason JM. Prevalence of gingival overgrowth induced by calcium channel blockers: a community-based study. J Periodontol. 1999 Jan;70(1):63-7.

18. Sousa CP, Navarro CM, Sposto MR. Clinical assessment of Nifedipine-induced gingival overgrowth in a group of brazilian patients. ISRN Dent. 2011; 2011:102047.

19. Ainamo J, Bay I. Problems and proposals for recording gingivitis and plaque. Int Dent J. 1975 Dec;25(4):229-35.

20. Miller CS, Damm DD. Incidence of verapamil-induced gingival hyperplasia in a dental population. J Periodontol. 1992 May;63(5):453-6.

21. Seymour RA, Smith DG, Turnbull DN. The effects of phenytoin and sodium valproate on the periodontal health of adult epileptic patients. J Clin Periodontol. 1985 Jul;12(6):413-9.

22. O'Leary TJ, Drake RB, Naylor JE. The plaque control record. J Periodontol. 1972 Jan;43(1):38.

23. Beck JD, Löe H. Epidemiological principles in studying periodontal diseases. Periodontol 2000. 1993 Jun;2:34-45.

24. Tavassoli S, Yamalik N, Çaglayan F, Çaglayan G, Eratalay $\mathrm{K}$. The clinical effects of nifedipine on periodontal status. J Periodontol. 1998 Feb;69(2):108-12.

25. Huang W-T, Lu H-K, Chou H-H, Kuo MYP. Immunohistochemical analysis of Th1/Th2 cytokine profiles and androgen receptor expression in the pathogenesis of nifedipine-induced gingival overgrowth. J Periodontal Res. 2003 Aug;38(4):422-7.

26. Miranda J, Brunet L, Roset P, Berini L, Farré M, Mendieta C. Prevalence and risk of gingival enlargement in patients treated with nifedipine. J Periodontol. 2001 May;72(5):60511.

27. Thomason JM, Seymour RA, Ellis JS, Kelly PJ, Parry G, Dark J, Idle JR. Iatrogenic gingival overgrowth in cardiac transplantation. J Periodontol. 1995 Aug;66(8):742-6.

28. Spolidorio LC, Spolidorio DM, Benatti C, Sampaio JE, Almeida OP. Combined effects of cyclosporin and nifedipine on gingival overgrowth in rats is not age dependent. J Periodontal Res. 2003 Aug;38(4):375-9.

29. Bullon P, Pugnaloni A, Gallardo I, Machuca G, Hevia A, Battino M. Ultrastructure of the gingiva in cardiac patients treated with or without calcium channel blockers. J Clin 
Periodontol. 2003 Aug;30(8):682-90.

30. Johnson R B. Synergistic enhancement of collagenous protein synthesis by human gingival fibroblasts exposed to nifedipine and TNF-alpha in vitro. J Oral Pathol Med. 2003 Aug;32(7):408-13.

31. Kataoka M, Shimizu Y, Kunikiyo YA, Azuma H, Sawa T, Kido J-I, et al. Nifedipine induces gingival overgrowth in rats through a reduction in collagen phagocytosis by gingival fibroblasts. J Periodontol. 2001 Aug;72(8):107883.

32. Shimizu Y, Kataoka M, Seto H, Kido J-I, Nagata T. Nifedipine induces gingival epithelial hyperplasia in rats through inhibition of apoptosis. J Periodontol. 2002 Aug;73(8):861-7.
Received: $13 / 11 / 2012$

Accepted: 31/01/2013

\section{Corresponding author}

Andrea Carvalho De Marco Department of Social Science and Pediatric Dentistry - School of Dentistry of São José dos Campos Av. Eng. Francisco José Longo, $\mathrm{n}^{\circ} 777$ - Jardim São Dimas, São José dos Campos - SP, Brasil, CEP: 12245-000 Fone number: 55 (12) 3947-9046 / FAX: 55 (12) 3947-9010 e-mail: andrea@fosjc.unesp.br 